\title{
Pembelajaran Ekonomi Berdasarkan Nilai-Nilai Pancasila dan Pasal 33 UUD'45 melalui Pembelajaran Proyek
}

\author{
Kholidya Khulafaur Rosidah ${ }^{1}$, Sugeng Hadi Utomo ${ }^{1}$, Hari Wahyono ${ }^{1}$ \\ ${ }^{1}$ Pendidikan Ekonomi-Universitas Negeri Malang
}

\begin{tabular}{l}
\hline \hline INFO ARTIKEL \\
\hline Riwayat Artikel: \\
Diterima: $31-07-2019$ \\
Disetujui: $14-09-2019$ \\
\hline
\end{tabular}

\section{Kata kunci:}

economic learning;

Pancasila economy; project learning;

pembelajaran ekonomi;

ekonomi pancasila;

pembelajaran proyek

\author{
Alamat Korespondensi: \\ Kholidya Khulafaur Rosidah \\ Pendidikan Ekonomi \\ Universitas Negeri Malang \\ Jalan Semarang 5 Malang \\ E-mail: kholidya.kr@gmail.com
}

\begin{abstract}
ABSTRAK
Abstract: This article aims to develop the learning design of Pancasila Economics in the form of learning scenarios that contain the values of Pancasila values and Article 33 UUD ' 45 in high school. Field trials were carried out in the Cross-Interest Class of the SMAN 1 Turen Malang Regency. The approach in this study uses Design Based Research. The development products compiled have gone through expert team validation stages of $93 \%$ and practitioners of $88 \%$, which means that the product of this learning scenario is very feasible to use. The results of the study on students gave positive results seen from three aspects of assessment, knowledge, attitudes and skills that showed an average yield above $70 \%$.

Abstrak: Artikel ini bertujuan untuk menyusun dan mengembangkan desain pembelajaran Ekonomi Pancasila berupa skenario pembelajaran yang mengandung nilai nilai-nilai Pancasila dan Pasal 33 UUD'45 di SMA. Uji coba lapangan dilakukan di kelas Lintas Minat Ekonomi SMAN 1 Turen kabupaten Malang. Pendekatan dalam penelitian ini menggunakan Design Based Reseach. Produk pengembangan yang disusun sudah melalui tahap validasi tim ahli sebesar $93 \%$ dan praktisi sebesar $88 \%$ yang artinya produk skenario pembelajaran ini sangat layak untuk digunakan. Hasil penelitian terhadap siswa memberikan hasil positif yang dilihat dari tiga aspek penilaian, yaitu pengetahuan, sikap, dan keterampilan yang menunjukkan hasil rata-rata diatas $70 \%$.
\end{abstract}

Sistem ekonomi dapat diartikan sebagai sistem yang beroperasi pada bidang ekonomi yang berkaitan dengan ideologi yang dianut masyarakatnya. Sistem ekonomi bisa dipahami sebagai suatu kesatuan utuh dari berbagai macam elemen yang saling berkaitan dan bergantung serta bekerja berdasarkan suatu prosedur atau mekanisme tertentu yang didasarkan pada ideologi suatu negara, dan dihadapkan pada keterbatasan sumber daya, untuk mencapai suatu tujuan peningkatan kesejahteraan masyarakat. Hal ini dapat diartikan bahwa semua aktivitas ekonomi bangsa Indonesia harus berlandaskan pada sistem ekonomi Pancasila, dan bukan sistem ekonomi yang lain. Dengan sistem ekonomi Pancasila, bangsa Indonesia ingin mencapai tujuan kesejahteraan seluruh rakyat Indonesia. Pada kenyataannya tercermin pada semua aktivitas ekonomi yang harus melibatkan seluruh rakyat dan untuk semua rakyat. Menurut (Amir, 2013) Pancasila mencakup "aturan main" dalam kehidupan berekonomi atau dalam hubungan kegiatan ekonomi antar para pelaku ekonomi yang berlandaskan pada etika atau moral Pancasila dengan tujuan utamanya yaitu untuk mewujudkan sila kelima Pancasila. Sebagai komponen integral bangsa ini, kita harus sepakat bahwa Pancasila adalah konsep revolusioner yang memajukan peradaban, terutama bagi Indonesia, Pancasila serta membentuk karakter dan identitas bangsa yang besar, modern, bermartabat, dan beradab. Pancasila adalah ideologi bangsa yang harus menjadi semangat setiap denyut kehidupan warga negara dan aktivitas konstitusionalnya karena Pancasila dipandang sebagai media akulturasi dalam berbagai pemikiran parsial tentang agama, pendidikan, budaya, politik, sosial, dan bahkan ekonomi. Maka dengan menjadikan filosofi Pancasila sebagai bangsa, kita dapat mewujudkan nasionalisme Indonesia.

Dalam penelitian Eunike menjelaskan lima prinsip Pancasila dalam hidup dengan sistem ekonomi Indonesia dimana sistem ekonomi Indonesia berbeda dengan sistem ekonomi komando dan sistem ekonomi liberal, kriteria "humanis" melekat cukup jelas untuk sistem ekonomi Indonesia. Oleh karena itu, sistem ini perlu menetapkan proses internalisasi untuk menciptakan perilaku ekonomi yang tepat sesuai dengan sistem ekonomi Indonesia. Sistem ekonomi Indonesia didasarkan pada Pancasila sebagai ideologi dan dasar negara bagi Indonesia. Karakteristik sistem ekonomi Indonesia didefinisikan dalam pasal 33 UUD 1945, ekonomi penuh rasa kebersamaan dan keakraban. Perspektif manusia menurut sistem ekonomi Indonesia adalah (1) orang yang lebih suka musyawarah dengan kerendahan hati untuk menyelesaikan masalah, (2) menganggap manusia sebagai keluarga, saling membantu, dan saling membantu satu sama lain, (3) umat manusia yang memiliki hasrat untuk bangsa dan negara, bersedia 
berkorban untuk memprioritaskan kepentingan dan kebahagiaan kelompok di atas kepentingannya sendiri, dan (4) umat manusia yang selalu memperhatikan keberlanjutan dan lingkungan dari kegiatan ekonomi. Oleh karena itu, orang Indonesia adalah manusia yang memiliki kehidupan yang seimbang, baik kehidupan manusia sebagai pribadi, hubungan manusia dengan manusia, hubungan dengan alam, hubungan manusia dengan masyarakat, hubungan manusia dengan umatnya, dan hubungan umat manusia dengan Tuhan mereka (Rose \& Lukiani, 2015).

Dalam kaitannya dengan praktik nilai-nilai Ekonomi Pancasila adalah berkaitan dengan adanya moralitas ekonomi, seperti halnya yang dijelaskan Mayasari yang menyatakan bahwa moralitas berkaitan dengan tindakan seseorang dalam hubungan sosial, dimana seseorang yang memiliki moralitas lebih menekankan pada kepedulian terhadap orang lain. Contoh seseorang yang peduli, peka terhadap kondisi lingkungan dan selalu membantu orang yang membutuhkan bantuan. Konsep moral itu sendiri telah kita lihat pada uraian di atas, dalam tulisan ini akan dibahas tentang moralitas dalam ekonomi. Moralitas Ekonomi adalah bagian dari perilaku ekonomi berkenaan dengan sikap dan tindakan ekonomi seseorang dalam interaksi dengan orang atau kelompok orang lain yang menekankan orang yang peduli terhadap keberadaan orang lain. Berbicara tentang moralitas dalam perilaku ekonomi melibatkan paradigma yang cenderung sebaliknya. Moralitas berbicara tentang kepedulian terhadap orang lain, sementara paradigma perilaku ekonomi yang didasarkan pada rasionalitas yang diterima secara umum menekankan bagaimana memenuhi manfaat yang diharapkan (Mayasari, 2015).

Dalam perkembangannya realita kehidupan berekonomi pada bangsa Indonesia cenderung mengarah ke kapitalis/liberalis dan telah meninggalkan ciri sistem ekonomi Pancasila. Sebenarnya, jika bangsa Indonesia dalam kehidupan ekonominya lebih merealisasi sistem ekonomi kapitalis/liberalis dan meninggalkan sistem ekonomi Pancasila maka bangsa Indonesia telah memperkuat posisi keterjajahan dari pada kemandirian ekonominya. Warisan sejarah bangsa Indonesia yang telah terjajah secara politik dan kedaulatannya telah memengaruhi pola pikir, mental, dan perilakunya yang mengarah pada keadaan penguatan keterjajahannya, termasuk di bidang ekonomi. Oleh karena itu, pendidikan ekonomi sangat diperlukan perannya untuk mengembalikan pada jati diri perekonomian Indonesia yang seharusnya, yakni perekonomian dengan sistem ekonomi Pancasila. Hasil penelitian Tahir menunjukkan bahwa penerapan sistem ekonomi Pancasila dalam pembelajaran ekonomi di Fakultas Ekonomi Universitas Negeri Makassar sudah dilaksanakan, tetapi tidak diajarkan sebagai subjek independen, kurang literatur dan tidak ada teori yang disepakati tentang sistem ekonomi Pancasila sehingga hanya terintegrasi dengan beberapa mata pelajaran terkait. Pendidikan ekonomi harus didasarkan pada nilai-nilai luhur Pancasila sebagai ideologi kami. Oleh karena itu, diperlukan upaya untuk meningkatkan penerapan sistem ekonomi Pancasila dalam pembelajaran Ekonomi. Selain itu, sistem ekonomi Pancasila harus ditempatkan dalam mata pelajaran (Ilyas \& Tahir, 2015).

Pembelajaran Ekonomi yang seharusnya ada di sekolah atau yang harusnya disuguhkan oleh lembaga pendidikan terakait materi Ekonomi yang substansial adalah materi yang didalamnya berisi konsep-konsep ataupun prinsip-prinsip yang memuat nilai-nilai perekonomian yang sudah disesuaikan dengan nilai-nilai Pancasila dan UUD'45 Pasal 33, dimana kedua hal tersebut menjadi dasar dalam melakukan kegiatan berekonomi. Pendidikan Ekonomi yang tersedia disekolah harusnya mampu membekali siswa untuk dapat menginternalisasikan nilai-nilai Pancasila dan UUD'45 khususnya Pasal 33 ke dalam kegiatan berekonomi dalam masyarakat. Realitanya dalam pembelajaran Ekonomi yang ada di sekolah dan sudah disediakan oleh lembaga pendidikan adalah pembelajaran Ekonomi yang didalamnya mengandung materi pembelajaran yang mayoritas didominasi oleh konsepkonsep Ekonomi liberal maupun kapitalis. Dimana konsep perekonomian liberal dan kapitalis ini sangat bertolak belakang dengan jati diri bangsa Indonesia, konsep tersebut meyakini bahwa masyarakat sebagai homo economicus, dimana mereka selalu mengejar kepentingan diri sendiri secara efisien. Efisiensi ekonomi yang diyakini paham tersebut adalah hanya akan terwujud melalui maksimisasi keuntungan dan meminimalisir biaya. Mereka menganggap bahwa efisiensi dapat dicapai hanya melalui persaingan pasar sehingga menurut pemahaman dalam konsep ini yang diunggulkan adalah letak persaingannya bukan pada kerja samanya. Dampak dari pemahaman ini adalah terlahirnya SDM yang lebih condong memiliki sifat untuk aktif mengeksploitasi dalam melakukan kegiatan perekonomian di masyarakat, khususnya yang berkaitan dengan pengelolaan SDA sebagai alat pemenuhan kebutuhan manusia (Rahmatullah, 2018).

Masalah tren global yang mampu menghilangkan nilai-nilai bangsa membuat kita berpikir tentang solusinya. Salah satu cara strategis yang dapat dilakukan adalah dengan memperkuat nilai-nilai bangsa yang sesuai dengan identitas nasional melalui pendidikan. Oleh karena itu, akan ada sumber daya manusia yang memiliki kualitas baik yang diharapkan mampu mengaburkan martabat bangsa seperti harapan dalam penyelenggaraan pendidikan nasional. Kualitas sumber daya manusia yang baik dapat dicapai jika pendidikan yang dilaksanakan bersifat komprehensif dan memiliki karakter atau lokalitas sesuai dengan identitas nasional. Selain itu, implementasinya dilakukan merata sehingga keadilan dalam pendidikan dapat dicapai oleh semua masyarakat. Oleh karena itu, program pendidikan dapat memberikan kontribusi bagi kesejahteraan masyarakat sehingga proses pembangunan dapat dilakukan secara berkelanjutan (Rahmatullah, 2018).

Pentingnya pembelajaran ekonomi yang sesuai dengan ideologi bangsa Indonesia dan bagaimana realita pembelajaran yang sudah ada sangat perlu dilakukan peninjauan dan rekomendasi melalui Redefinisi, Reorientasi, dan Redesain untuk mengatasi masalah tersebut. Menurut (Witjaksono, 2013) untuk mewujudkan demokrasi Ekonomi Pancasila, maka mulai dari substansi materi pelajaran, penggunaan media pembelajaran hingga praktik dalam kegiatan ekonomi 
haruslah berlandaskan pada nilai-nilai Pancasila. Hal ini terkait untuk mengontekstualisasikan materi dalam mata pelajaran Ekonomi seperti yang dirumuskan secara umum dalam KI (1-4). Siswa harus dibekali tidak hanya dengan pengetahuan dan keahlian, tetapi juga dengan karakter yang tinggi dan moral yang baik. Upaya yang diambil oleh pemerintah Indonesia, yaitu inisiatif revolusi mental untuk generasi muda harus didukung penuh oleh universitas sebagai jalan utama untuk menghasilkan generasi muda yang cerah dengan karakter yang baik. Negara dengan ideologi Indonesia, Pancasila menawarkan nilai-nilai moral yang komprehensif sebagai referensi untuk membangun karakter generasi muda yang baik secara nasional. Nilai-nilai moral yang terkandung dalam ideologi negara Pancasila yaitu nilai-nilai ketuhanan, kemanusiaan, persatuan, demokrasi, dan keadilan harus diajarkan secara menyeluruh di kelas-kelas dan diintegrasikan dalam kurikulum universitas untuk membangun karakter generasi muda masa depan yang baik (Saiful, 2019).

Project Based Learning merupakan suatu pembelajaran yang orientasinya kepada siswa dalam hal menggali pengetahuan yang kedepannya akan memperkaya pengetahuan untuk dapat menyelesaikan masalah yang ada. Nantinya Project Based Learning ini akan dapat memberikan penilaian alternatif kepada diri siswa dengan baik dikarenakan siswa harus bisa aktif menunjukkan apa yang sudah mereka ketahui, dimaa nantinya siswa akan diarahkan untuk bisa membawa pengetahuan yang sudah mereka peroleh sebelumnya dan pengetahuan baru yang ia peroleh serta kemampuan yang relevan dalam hal memecahkan masalah yang nyata. Dikarenakan hakikat pengerjaan proyek bersifat kolaboratif, maka pengembangan keterampilan tersebut ditunjukkan untuk semua tim. Pembelajaran berbasis proyek (PjBL) dengan cepat muncul sebagai pendekatan dinamis untuk mengajar. Metode ini memungkinkan siswa untuk mengeksplorasi masalah dan tantangan nyata dari kehidupan sehari-hari, sambil meningkatkan proses mendapatkan pengetahuan dan keterampilan, dan kemampuan untuk bekerja secara individu atau dalam kelompok kolaboratif kecil. PjBL, yang difokuskan pada siswa, biasanya digunakan dalam kurikulum teknik karena siswa terutama didorong oleh kebutuhan untuk merancang dan menciptakan produk akhir. Prinsip "perlu tahu/perlu lakukan" juga mendorong proses pembelajaran dan mengilhami mereka untuk menggali lebih dalam konsep (Jacques, Bissey, \& Martin, 2016). Demikian juga yang dipaparkan (Yılmaz ÇAKICI, 2013) bahwa PjBL merupakan pembelajaran yang memfokuskan pada bagaimana siswa berkreativitas, kerjasama tim untuk problem solving yang tentunya dengan keterampilan yang siswa dapat gali dan dilatih untuk menghasilkan suatu produk. Perspektif integratif pada motivasi dan pembelajaran telah menyebabkan minat baru dalam proyek siswa. Pembelajaran berbasis proyek adalah perspektif komprehensif yang berfokus pada pengajaran dengan melibatkan siswa dalam penyelidikan. Dalam kerangka kerja ini, siswa mencari solusi untuk masalah nontrivial dengan mengajukan dan memperbaiki pertanyaan, berdebat ide, membuat prediksi, merancang rencana dan/atau eksperimen, mengumpulkan dan menganalisis data, menarik kesimpulan, mengomunikasikan ide dan temuan mereka kepada orang lain, mengajukan pertanyaan baru, dan membuat artefak (Blumenfeld et al., 1991).

Pembelajaran berbasis proyek dianggap sebagai pendekatan untuk mengajar dimana siswa menanggapi pertanyaan atau tantangan dunia nyata melalui proses penyelidikan yang diperpanjang. Pertama, PjBL mengatur pembelajaran di sekitar proyek dan melibatkan siswa dalam situasi otentik dimana mereka dapat mengeksplorasi dan menerapkan materi pelajaran untuk masalah yang kompleks dan relevan dengan praktik profesional yang sedang mereka persiapkan. Kedua, karakteristik PjBL adalah mengembangkan keterampilan berpikir siswa, memungkinkan mereka untuk memiliki kreativitas, mendorong mereka untuk bekerja sama, dan mengarahkan mereka untuk mengakses informasi sendiri dan untuk menunjukkan informasi ini. PBL biasanya meminta siswa untuk berpartisipasi dengan sukarela dalam kegiatan pembelajaran bermakna yang diusulkan, sebagian besar kerja tim. Ketiga, dalam lingkungan PjBL, siswa belajar terutama dengan membangun pengetahuan dan membuat makna melalui proses berulang pertanyaan, pembelajaran aktif, berbagi, dan refleksi. Ini layanan pembelajaran menekankan peluang pendidikan yang interdisiplin, berpusat pada siswa, kolaboratif, dan terintegrasi dengan masalah dan praktik dunia nyata. Keempat, telah dilaporkan bahwa pendekatan ini efektif dan banyak digunakan dalam berbagai pengaturan ruang kelas. Kelima, ada banyak penelitian dalam dekade ini yang menunjukkan bahwa pembelajaran berbasis proyek adalah strategi pengajaran yang efisien untuk meningkatkan motivasi belajar siswa dan membantu siswa untuk terlibat dalam kegiatan pembelajaran. Keenam, beberapa peneliti menunjukkan bahwa pembelajaran mandiri siswa sekolah dasar dapat dirangsang dalam kegiatan PBL. Ketujuh, beberapa hasil penelitian menunjukkan bahwa PjBL memiliki potensi untuk meningkatkan hasil siswa dalam ranah afektif termasuk sikap terhadap kimia dan keyakinan self-efficacy. Kedelapan, motivasi siswa dirangsang dalam berbagai cara di lingkungan PjBL, seperti diskusi kelompok formal dan informal, pertemuan penyelia reguler dan berbagi kepemimpinan. Kesembilan, bukti potensi pendekatan $\mathrm{PjBL}$, terutama memfasilitasi prestasi belajar dan motivasi siswa didokumentasikan dengan baik dalam studi sebelumnya (Chiang \& Lee, 2015).

Demi terwujudnya tujuan pendidikan yang diinginkan, pendidik/guru perlu sebuah teori yang mendasari atau mendukung agar pembelajaran Ekonomi Pancasila dapat tercapai. Teori yang dirasa cocok dalam pembelajaran seperti ini adalah teori belajar konstruktivisme, dimana dalam teori ini siswa diberi kebebasan untuk membangun pengetahuan mereka sendiri sehingga dalam proses belajar mengajar diperlukan pengalaman belajar yang dilakukan sendiri oleh siswa. Pengalaman belajar bisa juga dilakukan melalui pengalaman dalam menanggapi permasalahan yang mereka ketahui sehingga nantinya siswa dapat melakukan proses mengakomodasi dan mengasimilasi penyelesaian masalah melalui pengalaman yang pada akhirnya pengetahuan mereka akan terbentuk sesuai dengan yang mereka yakini. 
Konstruktvisme merupakan salah satu teori belajar yang memiliki pandangan tentang proses pembelajaran yang beranggapan bahwa dalam proses pembelajaran untuk memperoleh pengetahuan diawali dengan adanya konflik yang kognitif. Konflik kognitif yang dimaksud adalah melalui pengetahuan yang konstruk sendiri oleh siswa melalui pengalaman nyata dari hasil interaksi dengan lingkungannya. Filsafat teori belajar konstruktivisme ini menganggap bahwa pengetahuan merupakan hasil konstruksi manusia melalui interaksi dengan objek, fenomena pengalaman dan lingkungan mereka. Strategi pembelajaran yang dapat membantu guru ekonomi untuk berkembang adalah melalui pendekatan konstruktivis, dimana dalam konstruktivistik adalah mencari dan menggunakan pertanyaan dan gagasan siswa untuk memandu pelajaran dan instruksi; melibatkan siswa dalam bertanya, aktivitas membangun dan menjelaskan suatu model dan menyediakan waktu yang cukup untuk refleksi dan menganalisis ide-ide yang diberikan oleh siswa. Secara umum, pedagogi konstruktivis menentukan prinsip, tahapan pengajaran, strategi dan peran penting yang diharapkan dari guru yang memiliki implikasi penting untuk menjadi guru yang memiliki teladan dalam bidang ekonomi (Woldab, 2013). Paham kontruktivistik ini merupakan dasar berpikir kontekstual, dimana pengetahuan itu dibangun secara perlahan yang hasilnya akan diperluas dengan konteks yang terbatas dan tidak secara mendadak. Di dalam pengetahuan bukanlah hanya seperangkat fakta di lapangan, suatu konsep ataupun kaidah yang siap untuk diingat oleh manusia, melainkan manusianya haruslah bisa membangun pengetahuannya sendiri dan dapat memberikan arti tersendiri melalui pengalaman yang nyata. Konflik kognitif terjadi ketika adanya interaksi antara konsep awal yang didapat siswa dengan fenomena baru yang bisa diintegrasikan begitu saja. Dengan demikian, perlulah perubahan ataupun modifikasi struktur kognitif dalam mewujudkan keseimbangan, dan dalam peristiwa ini akan mengalami sustainable, selama siswa itu mendapatkan pengetahuan yang baru.

Diharapkan dengan adanya pengembangan pembelajaran Ekonomi Pancasila melalui pembelajaran berbasis proyek, dapat membantu siswa dalam mempelajari mata pelajaran Ekonomi pada umumnya dan prinsip-prinsip ekonomi pancasila dengan mudah pada khususnya. Tidak hanya itu, dengan adanya pengembangan produk pembelajaran yang berdasarkan Ekonomi Pancasila melalui pembelajaran proyek, bertujuan agar siswa dapat mengkaji ulang mengenai konsep-konsep ekonomi yang sudah ada dan dapat melatih sendiri memecahkan permasalahan-permasalahan ekonomi berlandaskan pancasila. melalui uraian diatas, peneliti dengan para ahli serta praktisi berkolaborasi untuk melaksanakan penelitian dengan mengembangkan produk pembelajaran Ekonomi Pancasila yang berbentuk skenario pembelajaran melalui PjBL. Maka dari itu peneliti mengangkat judul: "Pengembangan Pembelajaran Ekonomi Berdasarkan nilai-nilai Pancasila dan Pasal 33 UUD’45 Melalui Pembelajaran Proyek".

\section{METODE}

Pendekatan yang digunakan dalam penelitian ini adalah model pendekatan Design Based Research (DBR). Menurut (Alghamdi, 2013) penelitian tentang desain ini membantu penelitian dalam pendidikan untuk mengadopsi penelitian berbasis desain untuk menyelidiki berbagai masalah yang dihadapi dalam lingkungan pendidikan, karena itu akan berkontribusi secara efektif untuk mengatasi masalah serta dapat menjembatani kesenjangan dalam penelitian antara teori dan praktik. Aplikasi Design Based Research dalam pengembangan pembelajaran dalam penelitian ini memiliki alur proses penelitian dan pengembangan seperti ditampilkan pada gambar 1.

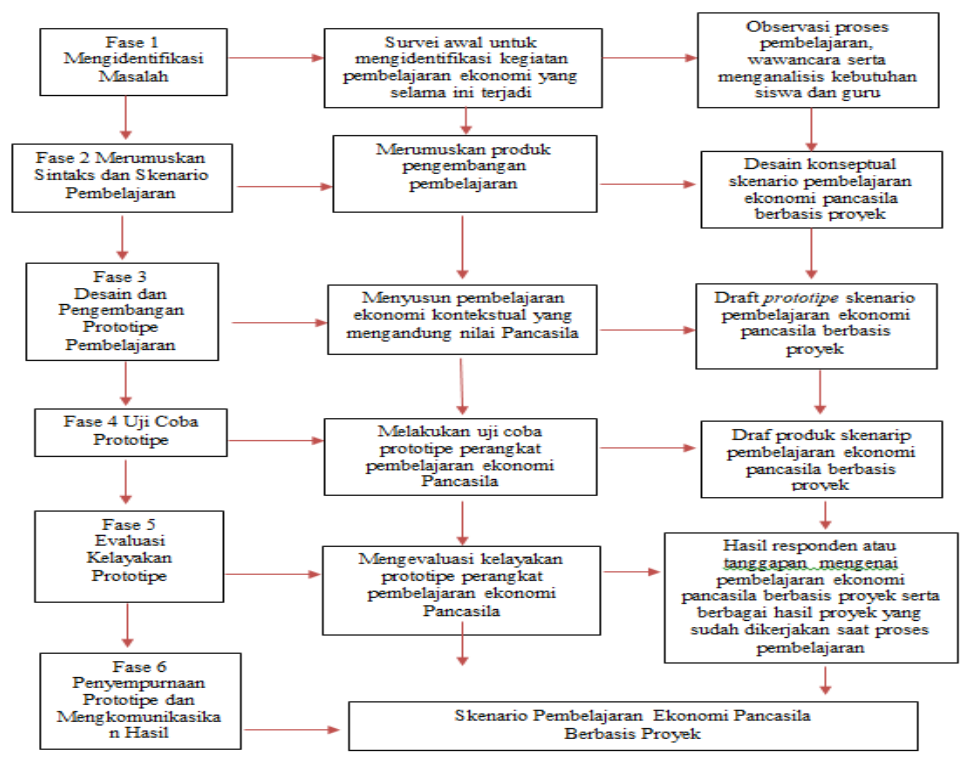

Gambar 1. Alur Pengembangan Pembelajaran Ekonomi Pancasila melalui Skenario Pembelajaran Berbasis Proyek 


\section{HASIL}

\section{Identifikasi Masalah dan Need Assesment}

Langkah awal dalam identifikasi masalah yang dilakukan oleh peneliti adalah melakukan wawancara tidak terstruktur kepada Ibu Etika dan beberapa siswa kelas X Lintas Minat Ekonomi mengenai pembelajaran Ekonomi di dalam kelas. Ringkasan dari hasil wawancara terdapat beberapa temuan permasalahan pembelajaran ekonomi yang ditampilkan pada tabel 1 .

Tabel 1. Ringkasan Hasil Temuan Permasalahan Pembelajaran Ekonomi

\begin{tabular}{|c|c|c|}
\hline & Keterangan & $\begin{aligned} \text { Hasil Temuan Permasalahan Pembelajaran Ekonomi } \\
\end{aligned}$ \\
\hline \multirow[t]{7}{*}{1} & Berdasarkan hasil wawancara tidak & Materi Ekonomi yang ada saat ini tidak memuat materi Ekonomi Pancasila \\
\hline & & Pembahasan Ekonomi Pancasila hanya sebatas memperkenalkan sekilas mengenai sistem \\
\hline & & Ekonomi di Indonesia tetapi tidak pernah ada materi Ekonomi Pancasila secara rinci dan jelas. \\
\hline & & $\begin{array}{l}\text { Guru tidak pernah memberikan materi Ekonomi Pancasila dikarenakan mengacu pada silabus } \\
\text { yang sudah ada yang tidak memuat sama sekali materi Ekonomi Pancasila }\end{array}$ \\
\hline & & $\begin{array}{l}\text { Pembelajaran ekonomi dikelas juga mengacu pada Buku Paket yang ada, sedangkan di Buku } \\
\text { Paket juga tidak ada materi yang berkaitan dengan Ekonomi Pancasila. }\end{array}$ \\
\hline & & $\begin{array}{l}\text { Penggunaan sumber ajar lain jarang digunakan karena terpaku pada silabus dan buku paket } \\
\text { yang sudah ada. }\end{array}$ \\
\hline & & $\begin{array}{l}\text { Pembelajaran Ekonomi jarang dilakukan di luar kelas karena eksplorasi terhadap praktik } \\
\text { pembelajaran ekonomi dianggap cukup dilakukan di dalam kelas. }\end{array}$ \\
\hline & $\begin{array}{l}\text { Berdasarkan hasil wawancara tidak } \\
\text { terstruktur dengan siswa-siswi }\end{array}$ & $\begin{array}{l}\text { Pembelajaran Ekonomi di rasa monoton karena pembelajaran tidak pernah dilakukan di luar } \\
\text { kelas. }\end{array}$ \\
\hline & & $\begin{array}{l}\text { Istilah Ekonomi Pancasila dikenal siswa-siswi sekilas di dalam pembahasan materi sistem } \\
\text { ekonomi. }\end{array}$ \\
\hline & & $\begin{array}{l}\text { Istilah Ekonomi Pancasila dikenal siswa-siswi dalam mata pelajaran pendidikan } \\
\text { kewarganegaraan bukan dalam mata pelajaran ekonomi. }\end{array}$ \\
\hline
\end{tabular}

\section{Sumber: Peneliti, 2019}

Hasil need assesment dari penelitian ini (1) menunjukkan bahwa siswa selama mengikuti pembelajaran ekonomi sebesar $51 \%$ yang memiliki perasaan senang dan $49 \%$ yang memiliki perasaan tidak senang, hanya selisih $2 \%$ pembelajaran ekonomi yang berlangsung monoton karena tidak pernah dilakukan di luar, (2) 100\% pembelajaran ekonomi tidak pernah dilakukan di luar kelas, (3) sebanyak 97\% siswa menyatakan pembelajaran Ekonomi perlu dilakukan di luar kelas, (4) sebanyak 89\% siswa menyatakan bahwa tidak pernah mendengar istilah Ekonomi Pancasila, dan $11 \%$ menyatakan pernah hal ini sesuai yang tertera pada tabel 1 bahwa siswa kurang familiar dengan istilah Ekonomi Pancasila dalam mata pelajaran Ekonomi, tetapi mengenal istilah Ekonomi Pancasila dalam mata pelajaran Pendidikan Kewarganegaraan, (5) sebesar 68\% siswa menyatakan bahwa uang sangatlah penting bagi mereka dalam pemenuhan kebutuhan, dan (6) sebesar $49 \%$ siswa jarang memanfaatkan sesuatu yang ada dalam pemenuhan kebutuhan dan lebih mengutamakan untuk membeli.

\section{Perumusan Produk Pengembangan}

Pada tahap perumusan produk pengembangan pembelajaran Ekonomi Pancasila melalui Project Based Learning yang berupa skenario pembelajaran ini peneliti berkolaborasi dengan tim ahli yaitu Bapak Dr. Hari Wahyono, M.Pd selaku dosen dan praktisi yaitu Ibu Etika Dhewi Rahmawati, S.Pd selaku guru Ekonomi di SMAN 1 Turen. Tujuan pada tahap ini adalah menyiapkan desain konseptual yang adapun langkah-langkahnya, meliputi (1) pemetaan nilai-nilai Pancasila dan Pasal 33 UUD 1945, (2) merumuskan KI, KD, indikator pembelajaran serta tujuan pembelajaran, (3) mengidentifikasi materi dasar Ekonomi Pancasila yang diajarkan di SMA, dan (4) merumuskan sintaks pembelajaran Ekonomi Pancasila untuk SMA. Hal ini dilakukan bertujuan untuk melakukan redesain, redefinisi, dan reorientasi terhadap mata pelajaran Ekonomi. Berikut pemaparan yang dijelaskan pada tabel 2. 
Tabel 2. Pemetaan Nilai-nilai Pancasila dan Pasal 33 UUD 1945 dalam Pengembangan Pembelajaran Ekonomi Pancasila

\begin{tabular}{|c|c|c|}
\hline \multicolumn{2}{|r|}{ Pancasila } & Nilai-Nilai \\
\hline & Sila ke-1 pada Pancasila & Religius, Keimanan \\
\hline & Sila ke-2 pada Pancasila & Hak Asasi Manusia \\
\hline & Sila ke-3 pada Pancasila & Kebangsaan \\
\hline & Sila ke-4 pada Pancasila & Demokrasi \\
\hline & Sila ke-5 pada Pancasila & Kesetaraan \\
\hline \multicolumn{2}{|r|}{ Pasal 33 UUD 1945} & Nilai-Nilai \\
\hline Ayat 1 & Perekonomian disusun sebagai usaha bersama berdasarkan asas kekeluargaan. & $\begin{array}{l}\text { Kebersamaan, brotherhood, gotong } \\
\text { royong, bekerjasama, demokratis, }\end{array}$ \\
\hline Ayat 2 & $\begin{array}{l}\text { Cabang-cabang produksi yang penting bagi negara dan yang menguasai hajat } \\
\text { hidup orang banyak dikuasai negara. }\end{array}$ & semangat kebangsaan dan cinta tanah air. \\
\hline Ayat 3 & $\begin{array}{l}\text { Bumi, air, dan kekayaan alam yang terkandung didalamnya dikuasai oleh negara } \\
\text { dan dipergunakan bagi sebesar-besarnya kemakmuran rakyat. }\end{array}$ & \\
\hline Ayat 4 & $\begin{array}{l}\text { Perekonomian nasional diselenggarakan berdasarkan atas demokrasi ekonomi } \\
\text { dengan prinsip kebersamaan, efisiensi, berkeadilan, berkelanjutan, berwawasan } \\
\text { lingkungan, kemandirian serta menjaga keseimbangan dan kesatuan ekonomi } \\
\text { nasional. }\end{array}$ & \\
\hline
\end{tabular}

Tabel 3. Perumusan KI, KD, Indikator dan Tujuan Pembelajaran

\begin{tabular}{|c|c|}
\hline Keterangan & Penjabaran \\
\hline \multirow[t]{2}{*}{ Kompetensi Inti } & $\begin{array}{l}\text { KI 3: Memahami, menerapkan dan menganalisis pengetahuan faktual, konseptual, prosedural, dan metakognitif } \\
\text { berdasarkan rasa ingin tahunya tentang ilmu pengetahuan, teknologi, seni, budaya dan humaniora dengan wawasan } \\
\text { kemanusiaan, kebangsaan, kenegaraan dan peradaban terkair penyebab fenomena dan kejadian, serta menerapkan } \\
\text { pengetahuan prosedural pada bidang kajian yang spesifik sesuai dengan bakat dan minatnya untuk memecahkan } \\
\text { masalah. }\end{array}$ \\
\hline & $\begin{array}{l}\text { KI 4: Mengolah, menalar, dan manyaji dalam ranah konkret dan ranah abstrak terkait dengan pengembangan dari } \\
\text { yang dipelajarinya disekolah secara mandiri, bertindak secara efektif dan kreatif, serta mampu menggunakan } \\
\text { metode sesuai dengan kaidah keilmuan. }\end{array}$ \\
\hline \multirow{2}{*}{$\begin{array}{l}\text { Kompetensi } \\
\text { Dasar }\end{array}$} & KD 3.1 Memahami dan menganalisis permasalahan penerapan nilai-nilai dalam Pancasila dan UUD 1945 pasal 33. \\
\hline & $\begin{array}{l}\text { KD 4.1 Menyajikan hasil analisis dan menerapkan makna yang terdapat dalam nilai Pancasila dan UUD’45 pasal } \\
\text { 33. }\end{array}$ \\
\hline \multirow{3}{*}{$\begin{array}{l}\text { Indikator } \\
\text { Pencapaian } \\
\text { Kompetensi }\end{array}$} & Menjelaskan ekonomi yang berlandaskan Pancasila dan UUD 1945. \\
\hline & $\begin{array}{l}\text { Memberikan contoh penerapan nilai-nilai Pancasila dan UUD } 1945 \text { pasal } 33 \text { dalam kehidupan sehari-hari yang } \\
\text { berhubungan dengan kegiatan ekonomi. }\end{array}$ \\
\hline & $\begin{array}{l}\text { Merinci permasalahan kegiatan ekonomi dalam kehidupan sehari-hari berlandasakan nilai-nilai Pancasila dan } \\
\text { UUD } 1945 \text { pasal 33. 4. Menganalisis permasalahan kegiatan ekonomi dalam kehidupan seharihari berlandasakan } \\
\text { nilai-nilai Pancasila dan UUD } 1945 \text { pasal 33. 5. Penerapan kegiatan ekonomi dalam kehidupan sehari-hari } \\
\text { berlandasakan nilai-nilai Pancasila dan UUD } 1945 \text { pasal } 33 \text {. }\end{array}$ \\
\hline Tujuan & Kognitif atau Pengetahuan \\
\hline \multirow[t]{5}{*}{ Pembelajaran } & Peserta didik mampu menjelaskan konsep dasar ekonomi pancasila dan UUD 1945 pasal 33. \\
\hline & Peserta didik mampu mendeskripsikan nilai-nilai ekonomi pancasila dan UUD 1945 pasal 33. \\
\hline & $\begin{array}{l}\text { Peserta didik mamu memberikan contoh penerapan nilai-nilai Pancasila dan UUD } 1945 \text { pasal } 33 \text { dalam kehidupan } \\
\text { sehari-hari yang berhubungan dengan kegiatan ekonomi. }\end{array}$ \\
\hline & $\begin{array}{l}\text { Afektif atau Sikap } \\
\text { Peserta didik mampu menunjukkan perubahan perilaku yang mencerminkan Pancasila dan UUD } 1945 \text { pasal } 33 \\
\text { berupa nilai ketuhanan, kemanusiaan, kerjasama, tolong menolong (gotong royong), tanggung jawab, demokrasi } \\
\text { ekonomi, dan kesetaraan. }\end{array}$ \\
\hline & $\begin{array}{l}\text { Pskimotorik atau Keterampilan } \\
\text { Peserta didik menunjukkan keterampilan atas performance mereka sesuai dengan Pancasila dan UUD } 1945 \text { pasal } \\
33 \text { pada saat proses pembelajaran. }\end{array}$ \\
\hline
\end{tabular}


Nilai Ketuhanan(sila ke 1 Panca sila)

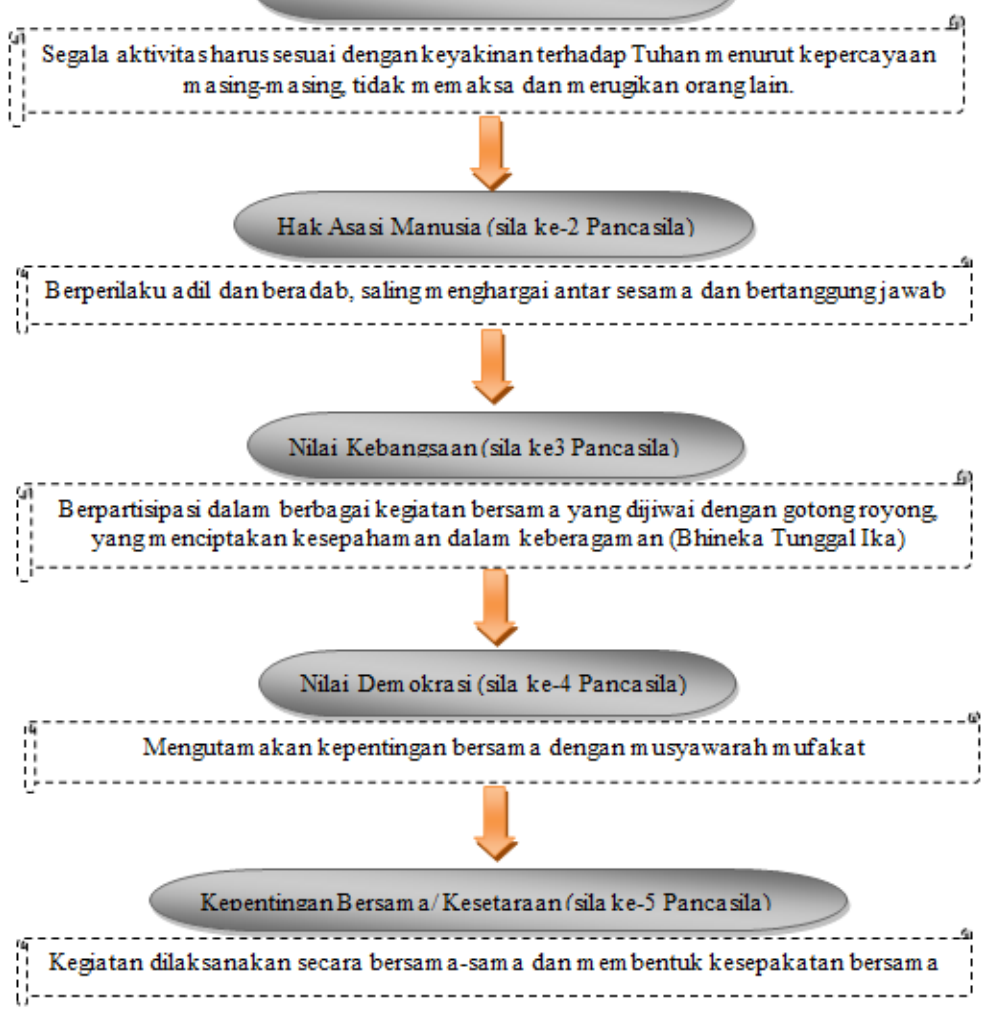

Gambar 2. Sintaks Pembelajaran Ekonomi Pancasila

Desain dan Pengembangan Produk

Pada tahap desain pengembangan, adapun langkah-langkah penyusunan desain pengembangan pembelajaran Ekonomi Pancasila sebagai berikut. Pertama, menyusun prototipe skenario pembelajaran yang didasarkan pada perumusan pengembangan produk yang sudah dibahas pada bab sebelumnya. Kedua, validasi materi dan skenario pembelajaran oleh ahli materi dan praktisi. Ketiga, revisi yang dilakukan setelah mendapat masukan dari para ahli dan praktisi untuk penyempurnaan prototipe sebelum diuji cobakan. Keempat, draft prototipe berupa skenario pembelajaran siap diujicobakan di lapangan. Jika digambarkan pada bagan langkah-langkah dalam penyusunan desain pengembangan produk dapat dilihat pada gambar 3 .

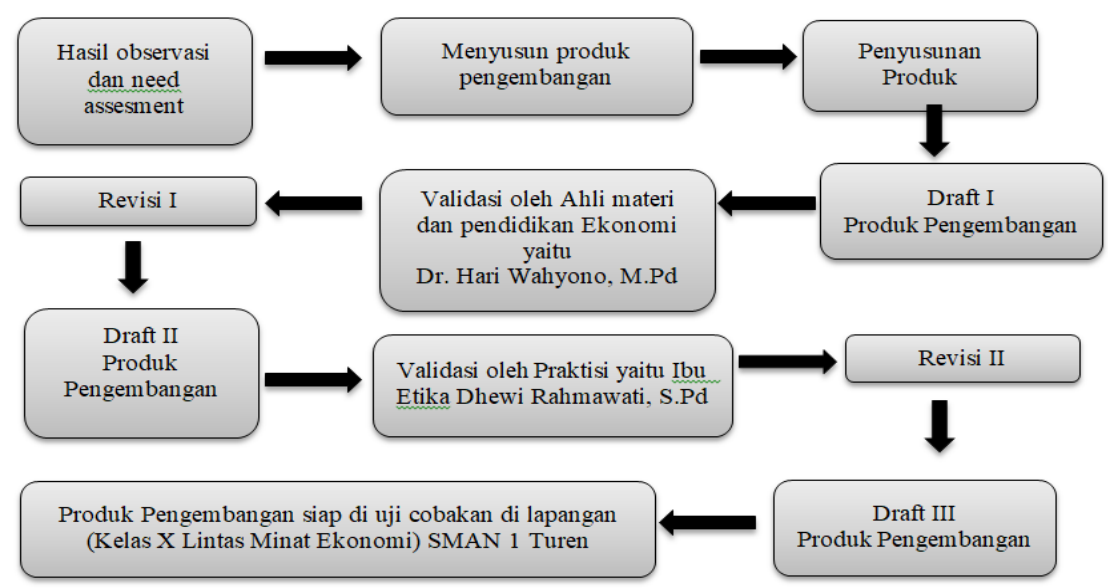

Gambar 3. Desain Pengembangan Produk 
Produk yang telah disusun sedemikian rupa mulai dari perumusan produk pengembangan hingga dikaitkan dengan pembelajaran berbasis proyek tidak serta merta langsung diujicobakan, melainkan hasil produk yang telah disusun perlu untuk divalidasikan kepada tim ahli dan praktisi. Berdasarkan hasil pengolahan data validasi ahli materi Pendidikan Ekonomi diperoleh skor validasi sebesar 93\% untuk aspek kelayakan materi dan diperoleh 93\% juga untuk kelayakan skenario pembelajaran, yang mana artinya tingkat pencapaian sebesar 93\% masuk dalam kualifikasi sangat layak dan produk yang dikembangkan peneliti dapat digunakan tanpa revisi. Peneliti juga memberikan hasil produk yang sudah disusun untuk divalidasi oleh praktisi dan diperoleh skor validasi sebesar $88 \%$, artinya tingkat pencapaian sebesar $88 \%$ masuk dalam kualifikasi sangat layak dan dapat digunakan di lapangan tanpa revisi.

Kesimpulan dari hasil validasi baik dari tim ahli dan praktisi menghasilkan bahwa produk yang dikembangkan sudah mencapai tujuan pembelajaran Ekonomi Pancasila. Namun, ada sedikit catatan dari tim ahli dan praktisi untuk penyempurnaan produk, yakni (1) ilustrasi diperkaya dan divariasikan, (2) penyajian produk dibuat semenarik mungkin agar kedepannya praktisi tertarik untuk mempraktikkan pembelajaran Ekonomi Pancasila, dan (3) sederhanakan langkah-langkah pembelajaran agar mudah dipahami oleh pengguna karena praktik pembelajarannya dilakukan di luar kelas.

\section{Uji Coba Produk}

Pada tahapan pengembangan ini, peneliti berkoordinasi dengan guru mata pelajaran Ekonomi yaitu Ibu Etika untuk keberlangsungan pelaksanaan uji coba produk pengembangan di kelas. Peneliti juga melakukan analisis situasi dan kondisi di kelas guna untuk keperluan praktik pembelajaran Ekonomi Pancasila melalui project based learning. Sebelum melakukan praktik peneliti juga berkoordinasi dengan guru terkait dengan waktu pelaksanaan.

Tabel 4. Rencana Praktik Pembelajaran Ekonomi Pancasila

\begin{tabular}{cllll}
\hline Nama Tempat & \multicolumn{1}{c}{ Alamat } & \multicolumn{1}{c}{ Waktu } & \multicolumn{1}{c}{ Kelas } & \multicolumn{1}{c}{ Jumlah Siswa } \\
\hline \multirow{3}{*}{ SMAN 1 Turen } & Jl. Mayjend Panjaitan 65 & $10.00-12.15(27$ April 2019) & X Lintas Minat & 35 Siswa \\
& Turen Kabupaten Malang & $10.00-12.15(2$ Mei 2019) & Ekonomi & Laki-laki : 10 orang \\
& & & & Perempuan : 15 orang \\
\hline
\end{tabular}

Kegiatan pokok dalam pelaksanaan pembelajaran Ekonomi Pancasila melalui project based learning, meliputi (1) pendahuluan dan debriefing, (2) pengisian Self Inventory oleh siswa, (3) pelaksanaan FGD oleh siswa dengan cara berkelompok dan dilakukan musyawarah untuk menentukan kesepakatan bersama terhadap pilihan pengolahan sumber daya yang ada dalam perencanaan proyek, dan (4) evaluasi keseluruhan kegiatan pembelajaran Ekonomi Pancasila berbasis proyek.

Dalam uji coba pengembangan produk ada dua poin yang dianalisis, yaitu analisis potensi siswa terhadap praktik kegiatan Ekonomi Pancasila dan situasi kegiatan pembelajaran. Hasil dari analisis potensi siswa terhadap praktik kegiatan Ekonomi Pancasila dapat disimpulkan bahwa siswa secara tidak sadar sudah pernah melakukan kegiatan-kegiatan ekonomi yang dilandasi Pancasila, meskipun ada beberapa hal yang belum sesuai. Disini peran penelitilah yang mengembangkan pembelajaran Ekonomi Pancasila berbasis Proyek guna untuk menyadarkan siswa bahwa Ekonomi Pancasila ini sangat melekat pada kegiatan sehari-hari yang dilakukan atau dirasakan sendiri oleh siswa. Hasil potensi siswa ini akan menjadi bekal peneliti dan sebagai pertimbangan dalam pengembangan praktik pembelajaran Ekonomi Pancasila di kelas.

Kemudian hasil dari analisis situasi kegiatan dapat disimpulkan bahwa pada tahap persiapan ini pada intinya adalah untuk penyamaan persepsi siswa tentang Ekonomi Pancasila dan UUD'45 pasal 33 terkait dengan praktik pembelajaran berbasis proyek yang akan dilaksanakan. Dengan contoh-contoh yang sudah diberikan guru terkait praktik Ekonomi Pancasila dan UUD'45 Pasal 33 siswa mampu memahami dan mereka dapat memberikan contoh dengan benar setalah diberikan awalan pemberian contoh oleh guru. Kemudian pada tahap perencanaan dapat disimpulkan bahwa semua kelompok mampu terlibat aktif dalam musyawarah untuk mencapai mufakat dalam perencanaan kegiatan proyek. Semua kelompok tidak ada yang merasa terpaksa dan merasa nyaman dalam penentuan tugas proyek karena pembentukan kelompok hasil dari sosiometri (lampiran sosiometri). Semua kelompok memiliki rasa sepenanggungan dan tanggung jawab bersama atas tugas yang diperoleh dan kegiatan proyek yang akan dilaksanakan. Hal yang perlu diperhatikan dalam tahap perencanaan ini adalah penguatan kepada siswa bahwa kegiatan proyek ini adalah mengajarkan siswa bagaimana bermusyawarah, berdemokrasi, dan memiliki rasa tanggung jawab bersama agar semua siswa atau setiap kelompok merasa diperlakukan adil dan tidak ada keterpaksaan. Hasil dari tahap pelaksanaan adalah secara keseluruhan siswa atau semua kelompok berhasil melaksanakan kegiatan proyek dengan baik yang ditunjukkan dengan (1) setiap kelompok mampu merealisasikan perencanaan proyek yang dilakukan pada tahap perencanaan, (2) setiap kelompok terlibat aktif mengerjakan kegiatan proyek yang dapat dilihat di lampiran dokumentasi, (3) setiap anggota kelompok mampu mengelola waktu, tenaga, dan pikiran mereka guna mencapai tujuan tang sudah direncanakan, (4) setiap anggota kelompok mampu mengerjakan kegiatan proyek dengan prinsip efektif dan efisien yang ditunjukkan dengan laporan pelaksanaan proyek. 


\section{Evaluasi Uji Coba Produk Pengembangan}

Hasil dari praktik kegiatan pembelajaran Ekonomi Pancasila melalui proyek yang sudah dilaksanakan oleh siswa tampak beberapa hal positif yang dialami oleh siswa. Secara individu maupun kelompok, siswa telah mampu merasakan atau mengalami perubahan persepsi mengenai pembelajaran Ekonomi yang harusnya diajarkan di kelas. Hasil pencapaian siswa dapat dilihat melalui analisis penilaian terhadap siswa yang dilakukan dari awal dilaksanakannya pembelajaran hingga akhir pelaksanaan kegiatan proyek. Ada tiga aspek penilaian dalam kegiatan pembelajaran ini yaitu penilaian sikap, pengetahuan dan keterampilan.

Hasil ketercapaian penilaian sikap menunjukkan bahwa ada lima indikator yang telah dicapai siswa sebesar $80 \%$ untuk indikator semangat belajar, sebesar $77 \%$ untuk indikator tanggung jawab, sebesar $97 \%$ untuk indikator gotong royong, sebesar 97\% untuk indikator demokrasi, dan sebesar $77 \%$ untuk indikator percaya diri. Hasil ketercapaian penilaian keterampilan menunjukkan bahwa ada tiga indikator yang telah dicapai siswa sebesar $80 \%$ untuk indikator keaktifan dalam diskusi, sebesar $83 \%$ untuk indikator keterampilan berkolaborasi, dan sebesar $97 \%$ untuk indikator keterampilan pengelolaan waktu, tenaga dan pikiran. Hasil penilaian pengetahuan yang ditunjukkan dari masing-masing kelompok yaitu kelompok satu sebesar $88 \%$, kelompok dua sebesar 83\%, kelompok tiga sebesar 85\%, kelompok empat sebesar 90\%, kelompok lima sebesar $87 \%$ dan kelompok enam merupakan kelompok yang mendapat skor terendah dibandingkan kelompok lainnya yaitu sebesar 77\%. Hal ini tunjukkan dari hasil diskusi kelompok terkait pemantapan materi yang dilakukan pada akhir kegiatan pembelajaran.

Tanggapan atau respons siswa terhadap proses dan pelaksanaan secara keseluruhan terkait praktik pembelajaran Ekonomi Pancasila melalui project based learning dilakukan oleh peneliti dengan cara membagikan angket respons yang harus diisi oleh siswa. Ada tiga aspek untuk mengetahui respons siswa terhadap pembelajaran yaitu minat (sebanyak tiga pertanyaan), manfaat (sebanyak 10 pertanyaan) dan tingkat tidak lanjut (terdapat dua pertanyaan). Total keseluruhan pertanyaan yang diajukan kepada siswa adalah 15 pertanyaan. Hasil dari respons siswa yang ditunjukkan diagram diatas memuat tiga kriteria ketercapaian yaitu minat sebesar 95\%, manfaat sebesar 94\%, dan tindak lanjut sebesar 97\%. Berdasarkan data yang dihasilkan dapat disimpulkan bahwa minat dan antusias siswa terhadap pembelajaran Ekonomi Pancasila melalui project based learning dikatakan tinggi. Untuk kebermanfaatan pembelajaran dalam memahami konsep, prinsip, dan praktik kegiatan ekonomi yang berlandaskan Pancasila dan UUD 1945 Pasal 33 ini juga dinilai tinggi menurut siswa, dan yang terakhir untuk tindak lanjut dinilai tinggi juga oleh siswa dimana dapat diberi simpulan bahwa dalam PjBL ini khususnya dalam pembelajaran Ekonomi Pancasila perlu dikembangkan untuk penyempurnaan dalam penerapan pembelajaran Ekonomi yang berhubungan dengan praktik dalam kehidupan siswa sehari-hari atau secara riil.

Efektivitas dari pembelajaran Ekonomi Pancasila melalui project based learning dapat dilihat dari "Protokol FGI" yang dilakukan oleh guru untuk memperoleh kesan dan alasan siswa selama penerapan kegiatan pembelajaran Ekonomi Pancasila di kelas. Hasil dari wawancara melalui FGI menunjukkan bahwa pembelajaran yang sudah diterapkan dirasa sangat bermanfaat, seru dan menyenangkan bagi siswa. Kesimpulan yang didapat dari siswa bahwa pembelajaran Ekonomi Pancasila sangat dirasa sekali nilai-nilai Pancasila yang muncul dalam pembelajaran mulai dari kebersamaan, kekeluargaan, gotong royong, mutualisme. Mulai dari tahap diskusi untuk mencapai mufakat mereka belajar untuk saling menghargai pendapat, dalam pelaksanaan proyek mereka menerapkan nilai-nilai kebersamaan, gotong royong hingga pada tahap menikmati bersama hasil proyek yang dikerjakan bersama mereka merasakan keakraban antar teman. Sifat individualis yang sebelumnya mereka lakukan, seperti main HP sendiri ketika bersama, tetapi dalam pengerjaan pembelajaran proyek mereka jadi lebih sering untuk berkomunikasi antar teman, melakukan musyawarah mufakat untuk mendiskusikan pemenuhan kebutuhan yang beragam dengan sumber daya yang terbatas dan mengutamakan keinginan bersama dari pada keinginan pribadi. Hasil lainnya juga menunjukkan bahwa pembelajaran proyek membantu dalam penerapan kegiatan pembelajaran Ekonomi Pancasila dan UUD 1945 Pasal 33. Pembelajaran ini dirasa perlu untuk dikembangkan karena dirasa bermanfaat dan berdampak positif, tidak hanya aspek pengetahuan, melainkan juga mengubah sikap dan keterampilan siswa. Pada intinya pembelajaran ini sangat berpengaruh pada karakter siswa dalam melakukan kegiatan khususnya dalam kegiatan berekonomi yang dilakukan sehari-hari.

\section{Pengomunikasian Hasil Pengujian Produk Pengembangan}

Hasil pengujian pengembangan berupa skenario pembelajaran Ekonomi Pancasila yang diterapkan melalui project based learning ini dikemas dan disusun dalam laporan yang tentunya sudah melalui tahap revisi akhir yang diunggah pada jurnal ilmiah.

\section{PEMBAHASAN}

\section{Kajian terhadap Skenario Kegiatan Pembelajaran}

Keberhasilan dalam menyusun desain pembelajaran ditentukan oleh beberapa hal yaitu: perumusan sintaks desain pembelajaran dan pemahaman tentang orientasi proses pengembangan oleh tim ahli, praktisi dan peneliti. Terintegrasinya nilainilai Pancasila dan UUD 1945 Pasal 33 ke dalam KI dan KD, tujuan pembelajaran, serta materi pembelajaran yang dibentuk berdasarkan Pancasila dan UUD 1945 Pasal 33 sehingga silabus dan RPP dapat dirancang sesuai identifikasi dan analisis situasi. Pengembangan pembelajaran Ekonomi yang berlandaskan Pancasila dan UUD 1945 Pasal 33 dengan mengubah pola pikir, sikap dan keterampilan siswa sebagai reorientasi pembelajaran Ekonomi. Kerangka operasional skenario pembelajaran yang disusun 
dan diperbaiki atas saran-saran yang sudah melalui tahap validasi tim ahli dan praktisi serta identifikasi situasi dari hasil wawancara dengan praktisi terkait penerapan kegiatan Ekonomi yang berlandaskan Pancasila dan UUD 1945 Pasal 33 melaui pembelajaran berbasis proyek yang terdiri dari enam langkah.

Pengembangan pembelajaran yang telah dilakukan menghasilkan temuan yang sistematik terutama pada cara berpikir siswa, hal ini dibuktikan melalui hasil eksplorasi awal pemikiran siswa bahwa uang adalah segalanya, lebih mendahulukan kepentingan individu dari pada kelompok, dan dalam pemenuhan kebutuhan siswa tidak mempertimbangkan potensi sumber daya yang ada, atau bisa dikatakan sifat konsumtif siswa cenderung tinggi untuk memenuhi kebutuhannya. Hasil pengejawantahan penelitian ini sala halnya dengan makna UUD 45 Pasal 33 ayat 1 oleh Sri Edi S dalamWitjaksono (2013) yaitu ......"usaha bersama" merupakan perwujudan paham hidup berdampingan, dimana hal yang diutamakan yaitu menjunjung tinggi semangat kerjasama didalam gotong royong yang tidak mengedepankan kepentingan individu melainkan mengedepankan kepentingan keserikatan dan orang banyak.

Proses dalam penelitian pengembangan pembelajaran Ekonomi Pancasila ini mampu meningkatkan bagaimana cara berpikir, sikap maupun keterampilan siswa. Perubahan yang dapat dilihat dari cara berpikir siswa yaitu bagaimana mereka mampu mengaitkan materi dengan memecahkan permasalahan Ekonomi secara riil yang berlandaskan Pancasila dan UUD'45 Pasal 33. Untuk perubahan sikap dapat dilihat bagaimana siswa belajar untuk tidak mementingkan diri sendiri ketika pelaksanaan pembelajaran proyek berlangsung, mulai dari kegiatan musyawarah kelompok, perencanaan proyek, pelaksanaan proyek yang dilakukan di luar kelas hingga pada saat pelaporan hasil proyek. Kerjasama yang tampak sekali dalam kegiatan ini dan sangat dirasakan dampak positifnya bagi siswa, mereka mengakui sendiri bahwa dengan kegiatan pembelajaran seperti ini antar individu bisa saling menghargai pendapat, kekeluargaan yang begitu terasa ketika pelaksanaan proyek, yang tentunya hal ini belum pernah mereka lakukan sebelumnya dalam pembelajaran. Kemudian untuk perubahan keterampilan dapat dilihat dari keterampilan mereka melaksanakan proyek ketika mengelola waktu, tenaga dan pikiran secara efektif dan efisien yang ditunjukkan dalam laporan kegiatan proyek. Dalam kegiatan ini siswa diberi kebebasan untuk berkreativitas membuat laporan semenarik mungkin, dan hasil laporan mereka bervariasi ada yang dibuat dalam bentuk short video, bagan kegiatan di kertas manila yang disertai foto kegiatan dan ada juga yang berbentuk kliping. Hal ini menunjukkan bahwa kegiatan pembelajaran ini berdampak positif pada berbagai aspek penilaian dan siswa mampu melakukannya dengan baik.

\section{Kajian terhadap Interaksi Pembelajaran}

Interaksi dalam pembelajaran Ekonomi Pancasila yang tercipta di kelas, meliputi (a) siswa mempunyai rasa kepedulian terhadap sesama anggota kelompoknya; (b) kepedulian siswa mendorong mereka untuk ikut merasakan apa yang dirasakan anggota kelompoknya atau bisa disebut juga rasa sepenanggungan (tenggang rasa); (c) adanya kerjasama untuk mencapai tujuan yang ingin dicapai yang dilakukan bersama kelompok; (d) dalam perencanaan proyek masing-masing kelompok membagi tugas kepada anggotanya melalui musyawarah yang disepakati bersama; (e) timbulnya kepercayaan antar anggota kelompok yang dapat dilihat dari pemilihan ketua kelompok, begitu juga ketua kelompok yang mempercayakan kemampuan yang dimiliki tiap anggotanya; (f) adanya rasa tanggungjawab dari anggota kelompok dalam melaksanakan tugas yang sudah diberikan. Interaksi pembelajaran yang ditunjukkan siswa melalui praktik kegiatan proyek sudah mampu menciptakan situasi pembelajaran Ekonomi Pancasila.

\section{Kajian terhadap Hasil Produk Pengembangan Pembelajaran}

Hasil dari produk pengembangan pembelajaran mulai dari pemetaan situasi dan kondisi pembelajaran Ekonomi Pancasila melalui alur kegiatan pembelajaran berbasis proyek hingga adanya refleksi pembelajaran mampu menciptakan ketercapaian sintaks pembelajaran Ekonomi Pancasila yang mencakup beberapa hal, meliputi (1) terciptanya kegiatan atau aktivitas yang didasari oleh kesepakatan dan kesepahaman dalam proses berpikir secara individu maupun kelompok yang dijiwai oleh sila pertama Pancasila; (2) terciptanya kegiatan yang membentuk interaksi kekeluargaan sehingga menghargai antar sesama dan memiliki tanggung jawab bersama dapat dirasakan sebagai perwujudan sila kedua Pancasila; (3) terciptanya partisipasi dalam kegiatan bersama yang dijiwai dengan gotong royong yang dapat menciptakan kesepahaman dalam keberagaman kelompok yang tercermin pada sila ketiga Pancasila; (4) terciptanya kesejahteraan anggota kelompok yang diciptakan melalui musyawarah mufakat untuk memenuhi kepentingan bersama yang dijiwai oleh sila keempat Pancasila; (5) terbentuknya pengalaman yang dirasakan siswa dalam kegiatan pembelajaran Ekonomi Pancasila melalui project based learning yang dilakukan secara bersamasama dengan kelompok masing-masing melalui kesepakatan bersama yang didasari oleh sila kelima Pancasila. Adanya refleksi setelah kegiatan pembelajaran proyek melalui FGI guna untuk merefleksikan pengalaman yang didapat siswa ke dalam kehidupan sehari-hari dimana pondasi dalam berkegiatan Ekonomi adalah Pancasila dan UUD’45 Pasal 33. 


\section{Kelemahan dalam Pengembangan Pembelajaran}

Kegiatan praktik pembelajaran Ekonomi Pancasila melalui project based learning ini juga memiliki kelemahan dalam pelaksanaannya karena kegiatan proyek dilakukan di luar kelas monitoring yang dilakukan tidak bisa dilakukan langsung untuk memantau pekerjaan proyek, pendokumentasian juga harus diperhatikan agar segala bentuk aktivitas yang dilakukan bisa didokumentasikan dengan baik yang nantinya akan dilaporkan kepada guru sehingga guru bisa merefleksi kegiatan siswa. Kelemahan selanjutnya dalam interaksi pembelajaran ini adalah perbedaan karakteristik siswa, dimana tidak semua siswa memiliki keaktifan dalam mengikuti pembelajaran maupun keberanian menyampaikan pendapat sehingga peran guru disini diperlukan untuk mendorong dan memotivasi siswa yang kurang aktif atau menutup diri untuk bisa berani mengungkapkan pendapatnya.

\section{SIMPULAN}

Penelitian pengembangan ini menghasilkan produk skenario pembelajaran Ekonomi Pancasila yang mampu menciptakan situasi belajar siswa yang berlandaskan Pancasila dan UUD'45 Pasal 33 melalui project based learning, meskipun ada beberapa hal yang perlu diperhatikan terkait teknis pelaksanaan pembelajaran mulai dari persiapan terutama penguasaan materi Ekonomi Pancasila oleh guru, monitoring kegiatan proyek, serta pelaporan kegiatan proyek. Produk yang dikembangkan ini juga sudah melalui tahap validasi tim ahli sebesar 93\% dan praktisi sebesar 88\% yang artinya produk skenario pembelajaran ini sangat layak untuk digunakan.

Hasil penelitian pengembangan pembelajaran Ekonomi Pancasila melalui project based learning ini memberikan hasil positif terhadap perubahan pola pikir yang ditunjukkan melalui ketercapaian siswa mengaitkan materi dengan permasalahan Ekonomi secara riil, untuk perubahan sikap tercermin pada pelaksanaan proyek dimana dalam pelaksanaannya sudah mencakup semangat belajar, tanggung jawab, gotong royong, demokrasi dan percaya diri dimana hasil dari penilaian sikap sudah menunjukkan rata-rata diatas $70 \%$ dan yang terakhir adalah keterampilan siswa yang ditunjukkan melalui keaktifan dalam berdiskusi, keterampilan berkolaborasi, dan keterampilan dalam mengelola waktu, tenaga dan pikiran, hasil dari penilaian keterampilan juga menunjukkan rata-rata diatas $70 \%$. Konstruksi pengetahuan siswa berhasil dilakukan dengan baik sesuai tujuan yang ingin dicapai dan ditunjukkan siswa melalui kegiatan FGI.

Skenario pembelajaran Ekonomi Pancasila ini dapat dipraktikkan secara fleksibel melihat kondisi lingkungan belajar siswa, yang artinya skenario pembelajaran ini bisa dimodifikasi sesuai dengan situasi yang terjadi di lapangan. Produk pembelajaran yang sudah dikembangkan peneliti dikatakan layak dan efektif untuk diterapkan, tetapi masih perlu dikembangkan lagi guna membelajarkan materi Ekonomi Pancasila yang berlandaskan Pancasila dan UUD’45 Pasal 33.

Saran untuk pengembangan yang akan dilakukan oleh peneliti selanjutnya adalah eksplorasi lebih dalam terkait praktik kegiatan Ekonomi Pancasila yang bisa dilakukan oleh siswa, terutama yang berkaitan dengan kehidupan sehari-hari. Memahami karakteristik dan lingkungan sekitar siswa juga perlu dilakukan terlebih dahulu guna sebagai bahan untuk membuat skenario pembelajaran dan perumusan kegiatan pembelajaran Ekonomi Pancasila.

\section{DAFTAR RUJUKAN}

Alghamdi, A. H. (2013). Adapting Design-Based Research as a Research Methodology in Educational Settings. International Journal of Education and Research, 1(10), 1-12. https://doi.org/10.1016/j.emj.2010.10.004

Amir, S. (2013). Pancasila as Integration Philosophy of Education and National Character. International Journal of Scientific and Technology Research, 2(1), 54-57.

Blumenfeld, P. C., Soloway, E., Marx, R. W., Krajcik, J. S., Guzdial, M., \& Palincsar, A. (1991). Motivating Project-Based Learning: Sustaining the Doing, Supporting the Learning. Educational Psychologist, 26(3-4), 369-398. https://doi.org/10.1080/00461520.1991.9653139

Chiang, C. L., \& Lee, H. (2015). The Effect of Project-Based Learning on Learning Motivation and Problem-Solving Ability of Vocational High School Students. International Journal of Information and Education Technology, 6(9), 709-712. https://doi.org/10.7763/ijiet.2016.v6.779

Ilyas, M., \& Tahir, T. (2015). The Implementation of Pancasila Economic System in Economic Learning at Faculty of Economics State University of Makassar. IOSR Journal of Economics and Finance Ver. III, 6(6), 2321-5933. https://doi.org/10.9790/5933-06636669

Jacques, S., Bissey, S., \& Martin, A. (2016). Multidisciplinary Project Based Learning Within a Collaborative Framework. International Journal of Emerging Technologies in Learning, 11(12), 36-44. https://doi.org/10.3991/ijet.v11i12.5996

Mayasari. (2015). Feminist Economy in Family Economic Education to Build Economic Morality of Pancasila. IOSR Journal of Economics and Finance Ver. II, 6(6), 2321-5933. https://doi.org/10.9790/5933-06623540

Rahmatullah, R. (2018). Pembelajaran Ekonomi Berjati Diri Bangsa. JEKPEND: Jurnal Ekonomi dan Pendidikan, l(1), 10. https://doi.org/10.26858/jekpend.v1i1.5055 
1201 Jurnal Pendidikan, Vol. 4, No. 9, Bln September, Thn 2019, Hal 1190-1201

Rose, E., \& Lukiani, M. (2015). Human Perspective in Indonesian Economic System. IOSR Journal of Humanities and Social Science Ver. IV, 20(11), 86-90. https://doi.org/10.9790/0837-201148690

Saiful. (2019). Building Good Character of Indonesian Young Generation with Moral Values of State Ideology of Pancasila . 24(1), 4-7. https://doi.org/10.9790/0837-2401100407

Witjaksono, M. (2013). Mengacu pada Amandemen Pasal 33 UUD 1945. Jurnal Pendidikan Ekonomi, 6(1), 1-12.

Woldab, Z. E. (2013). Constructivist Didactics in Teaching Economics: A Shift in Paradigm to be Exemplary Teacher. Academic Journal of Interdisciplinary Studies, 2(1), 197-204. https://doi.org/10.5901/ajis.2013.v2n1p197

Yılmaz ÇAKICI, N. T. (2013). An Investigation of the Effect of Project-Based Learning Approach on Children's Achievement and Attitude in Science. Tojsat, 3(2), 9-17. 